\title{
Model Taylora-Russella jako przykład podejścia portfelowego do pomiaru kapitału ludzkiego
}

\author{
TOMASZ KAWKA
}

Katedra Zarzadzania Kadrami, Uniwersytet Ekonomiczny we Wrocławiu

\begin{abstract}
Artykuł jest próbą konceptualizacji modelu użyteczności metod doboru zawodowego Taylora-Russela w zakresie dostosowania go do warunków pomiaru kapitału ludzkiego. $\mathrm{Na}$ podstawie założeń metodycznych modelu TR dokonuje się analizy zastosowania technik portfelowych w sprawozdawczości kapitału ludzkiego. Główną osią koncepcyjną jest transpozycja i zamiana kryteriów predykcyjnych w oryginalnym modelu na kryteria porządkujące podejmowanie decyzji personalnych. W konsekwencji przyjęto założenie, iż wartość kapitału ludzkiego jest zatem funkcją użyteczności realizacji odpowiednich procesów i programów zarządzania zasobami ludzkimi. Decyzja personalna, która okazuje się być trafioną (optymalną) ze względu na podjęte cele oraz środki, którymi organizacja dysponuje, uwarunkowana jest dwoma wymiarami: procesem decyzyjnym oraz wartością kapitału ludzkiego, w stosunku do którego podejmuje się decyzje.
\end{abstract}

Słowa kluczowe: kapitał ludzki, modele portfelowe, decyzje personalne, użyteczność, model Taylora-Russela.

\section{Wstęp}

Inwestycje w kapitał ludzki to wydatki organizacji, które prowadzą do akumulacji kapitału ludzkiego lub wzrostu jego produktywności. Są obarczone dużym ryzykiem, a stopa zwrotu jest niezwykle trudna do skalkulowania (Bochniarz, Gugała, 2005, s. 119). Nieadekwatność klasycznych standardów rachunkowości szacujących wartość organizacji, traktowanie wydatkowanych środków na rozwój kapitału ludzkiego przez zarządzających firmami jako kosztu, oraz uciążliwość metodyczna w szacowaniu stopy zwrotu sprawia, iż niezmiernie trudno jest przyjąć obiektywnie zdefiniowaną metodykę wyceny wartości tego kapitału. Brak 
pewności, co do takich zmiennych, jak: końcowa wartość inwestycji, sam okres trwania inwestycji, czynniki wpływające na zwrot z tych inwestycji - sprawia, że bardzo trudno jest w sposób jednoznaczny i decydujący przyjąć sformalizowaną metodykę pomiaru jego wartości.

Przyjmując dynamiczny kontekst (zmienność w czasie) oceny znaczenia i wpływu kapitału ludzkiego na powodzenie zarządzania całej organizacji, (czyli jego wartość) - można wskazać odmienne wskaźniki pomiaru oddziaływania kapitału ludzkiego. Biorąc pod uwagę kryterium efektywność funkcjonowania firmy w zależności od etapu, w którym pomiar kapitału będzie rozpatrywany, mogą to być następujące mierniki (np. Łukasiewicz, 2009, s. 115):

- Pomiaru kapitału ludzkiego na wejściu do organizacji - ocena zasobu/ stanu wejścia kapitału do firmy, ocena potencjalnej wartości (np. identyfikacja kompetencji, analiza wykształcenia i dopasowania do stanowiska, itp.)

- Pomiaru kapitału ludzkiego w trakcie inwestycji - ocena przejścia i transformacji kapitału, ocena przyrostu jego wartości (np. poziom wydatków na wynagrodzenia, koszty szkolenia i rozwoju itp., liczba szkoleń, przyrost wiedzy, itp.)

- Pomiaru kapitału ludzkiego uwidoczniony w wynikach jednostek organizacji - ocena efektów pracy, ocena uzyskanej wartości dodanej (np. wyniki i jakość uzyskanych wyników pracy, poziom fluktuacji, retencji, liczba awansów, wartość sprzedaży, itp.).

Kolejnym problemem komplikującym przyjęcie jednoznacznej metodyki pomiaru kapitału ludzkiego jest wielość podmiotów, różnorodność ich relacji oraz powiązań między nimi, które kształtują w całości w wymiarze epistemologicznym i ontologicznym, pojęcie i definicje kapitału ludzkiego (Grodzicki, 2003, s. 46-50; Łukasiewicz, 2009, s. 11-40; Strużyna 2000, s. 46-54). Trudność w konstruowaniu metod pomiaru wartości kapitału ludzkiego może mieć również swoje uzasadnienie w różnorodnych źródłach przejawiania się owej wartości w czynnikach organizacyjnych (Cascio, 2001, s. 15). Mogą to być np. koszty pozyskania i zastąpienia, bieżąca wartość przyszłych dochodów, aktualna wartość wynagrodzenia, koszty określonych zachowań pracowniczych, poziom oczekiwanych przychodów, czy inne wskaźniki ekonomiczne opisujące sytuację organizacji.

W tym świetle cechy, które powinny charakteryzować metody pomiaru kapitału ludzkiego według W. Cascio to: prostota metody i założeń, pomiar tego, co jest ważne z punktu widzenia strategii firmy, oraz dokonanie pomiaru tych działań, które przekładają się długofalowo na majątek intelektualny przedsiębiorstwa (Cascio, 2001, s. 24). W dużym stopniu metodą pomiaru zjawisk zarządczych i organizacyjnych, która spełnia powyższe założenia jest metoda portfelowa. 


\section{Metody portfelowe}

Celem niniejszego artykułu jest próba sformułowaniu założeń, ocena przydatności, oraz analiza ograniczeń wybranej metody portfelowej (model Taylora-Russela) - w kontekście pomiaru wartości kapitału ludzkiego, rozumianego jako wartość zwrotu z inwestycji. Do podejść, które pozwalają na takie analizy można zaliczyć szeroko rozumiane metody portfelowe (Stabryła, 2001, s. 178). Przyjmując podejście portfelowe jako metodę wyceny wartości kapitału ludzkiego należy dookreślić macierzową parę czynników wskazującą na dwa kluczowe aspekty wyceny decyzji personalnych - czynnik sukcesu oddziaływania na kapitał ludzki i warunek tego sukcesu. Do jednej z najbardziej znanych i popularnych metod w tym zakresie można zaliczyć model Taylora-Russela (TR) wyceny użyteczności stosowanej metody doboru pracowniczego (Cascio, 1980; Cascio, 2001; Chełpa, Kawka, 2005). W celu transkrypcji założeń z kanonicznej (dedykowanej selekcji zawodowej) wersji modelu TR w kierunku założeń pomiaru kapitału ludzkiego, w dalszej części tekstu zostaną omówione następujące kwestie:

- rola użyteczności w ocenie decyzji personalnych,

- relacje między użytecznością decyzji personalnych a wartością kapitału ludzkiego,

- szczegółowe założenia metodyki modelu TR przeniesione na założenia wyceny wartości kapitału ludzkiego.

Aby można było zastosować jakiekolwiek narzędzie do pomiaru wartości kapitału ludzkiego, należy na wstępie odpowiedzieć na następujące pytania:

1. Co chcemy mierzyć? - jak zdefiniować kapitał ludzki i jego składowe, aby można było ustalić jednoznacznie podmiot (składowe kapitału ludzkiego) i przedmiot (wskaźniki użyteczności decyzji personalnej oraz wyniki pracy) jego pomiaru?

2. Po co chcemy go mierzyć? - jakiego rodzaju zbiór informacji jest nam niezbędny w celu osiągnięcia systemowych celów biznesowych organizacji i zarządzania kapitałem ludzkim? Jak interpretować ilościowe wyniki uzyskane w podziale portfelowym?

3. Jak to chcemy zmierzyć? - jakiego rodzaju metodyka może być uznana za teoretycznie i empirycznie zweryfikowaną (możliwą do aplikacji) w kontekście przedmiotu i celów pomiaru? Jakie kryteria, predyktory, wskaźniki opisujące obszary funkcji personalnej - należy uwzględnić, aby uzyskać jednolite i łatwe do interpretacji wyniki pomiaru.

Metody portfelowe ułatwiają rozstrzyganie powyższych wątpliwości ze względu na swoją prostotę budowy, dwuwymiarowość podziału analizowanego 
i wycenianego zakresu, a przede wszystkim na możliwość czytelnej interpretacji przyczyn i skutków ulokowania się w danej kwarcie macierzy opisywanego zjawiska.

Portfelowe techniki oceny trafności procedur selekcyjnych są zwalidowanymi narzędziami dokonującymi pomiar użyteczności (sukcesu) decyzji personalnych w zakresie subfunkcji doboru pracowniczego. Tak uzyskane wyniki można odnosić do pomiaru zarówno aspektów oceny sprawności samego działania jak: trafność, rzetelność, predykcyjność czy użyteczność przeprowadzanych działań doboru pracowniczego (Kawka, Chełpa, 2005, s. 492). Z drugiej strony można w pośredni sposób opisać i interpretować uzyskane wskaźniki oceny poszczególnych składowych oddziaływania na pracowników w procesach personalnych, jako parametry pomiaru syntetycznej oceny jakości i użyteczności inwestycyjnej w pozyskanie, realizację i retencje kapitału ludzkiego. Opisywane w literaturze przedmiotu metody dedykowane wprost do pomiaru kapitału ludzkiego jawią się jako złożone, trudne, niejednoznaczne czy to w zakresie metod kosztowych, dochodowych, ważonych kosztów pracy, przyszłych zysków przedsiębiorstwa, wartości firmy, zrównoważonej karty wyników, metod kapitału przedsiębiorstwa, metod wskaźnikowych i innych (np. Lipka, 2012, s. 451-470; Edvinsson, Malone, 2001, s. 128-143; Bochniarz, Gugała, 2005, s. 119-150). Metody portfelowe wspomagają ocenę użyteczności określonej wartości zasobu czy kapitału w zależności od jednej zmiennej, zazwyczaj podzielonej binarnie. Daje to dużą przejrzystość i łatwość w szybkim umownym „wycenieniu” uzyskanych wyników - cztery pola, którym można przypisać określone wartości. W tym przypadku jest to użyteczność decyzji organizacji w stosunku do pracownika, który jest nośnikiem kapitału ludzkiego (Listwan, 2010).

W tym świetle można przyjąć, iż wartość kapitału ludzkiego jest zatem funkcją użyteczności realizacji odpowiednich procesów i programów zarządzania zasobami ludzkimi (Wawrzyniak, 2001). W związku z tym szacowanie określonych wielkości rozumianych jako wyznaczniki oceny użyteczności tych procedur (np. selekcja, coaching, wynagradzanie, szkolenia i rozwój, czy polityka awansowa) są pochodną wartości posiadanego kapitału ludzkiego, rozumianego jako zwrot z inwestycji owych decyzji (Cascio, 2001, s. 203). Wychodząc z takiego założenia można dokonać implementacji przykładowych modeli, które $\mathrm{w}$ praktyce i literaturze przedmiotu opisywane są do pomiaru kapitału ludzkiego w szerokim kontekście jego wpływu na sukces organizacji. Metody portfelowe wskazują na określoną wartość analizowanego przedmiotu pomiaru w kontekście kluczowych czynników strategii i sukcesu organizacji. Z pewnością do takich można zaliczyć kapitał ludzki i pomiar wartości, jaką generuje w kontekście określonych decyzji personalnych. 


\section{Użyteczność decyzji personalnych jako funkcja wartości kapitału ludzkiego}

Użyteczność jest działaniem mającym na celu identyfikację poziomów potencjalnych zysków oraz strat, które można osiągnąć podejmując określone celowe działania (Cascio, 2001). Spośród różnych strategii realizacji funkcji personalnej przedsiębiorstwo powinno wskazać te, które maksymalizuje użyteczność wszystkich potencjalnych procesów i procedur w danej wiązce oddziaływania na zasoby ludzkie. Decyzja personalna, która okazuje się być trafioną (optymalną) ze względu na podjęty cel oraz środki, którymi organizacja dysponuje jest uwarunkowana na poziomie strategicznym dwoma wymiarami: procesem decyzyjnym oraz wartością kapitału ludzkiego, w stosunku do którego podejmuje się decyzje. Szacowanie użyteczności jest zatem jednym z istotniejszych zakresów racjonalizacji teorii podejmowania decyzji (Bolesta-Kukułka, 2003), zwłaszcza wobec tak trudnego i złożonego do estymacji kapitału jakim są pracownicy i ich cechy, dyspozycje, postawy czy kompetencje. Kluczowym wymiarem, który warunkuje potencjalny sukces osiągnięcia optymalnych wyników użyteczności zarządzania zasobami ludzkimi jest potencjalna, jak i urzeczywistniona jakość oraz wartość kapitału ludzkiego. Wartościowy kapitał ludzki to taki, którego posiadanie umożliwia firmie realizację strategii poprawiających organizacyjną wydajność i ekonomiczną efektywność oraz wykorzystanie rynkowych okazji (Majowska, 2004, s. 37). Oczywiście, nie można założyć, iż te związki są oczywiste, prostoliniowe oraz bezpośrednio zależne (Cronbach, Gleser, 1965). Niemniej liczne artykuły w literaturze przedmiotu (np. Mikuła, Potocki, 2002; Domański, 1993; Rybak 2003, Bratnicki, Strużyna, 2002) oraz praktyka zarządzania zasobami ludzkimi (chociażby podejmowane $\mathrm{w}$ spotkaniach $\mathrm{w}$ ramach cyklu Konferencji Sukces w Zarządzaniu Kadrami) wskazuje na silną zależność między sukcesem organizacji, jakością funkcji personalnej, oraz jakością i wartością wygenerowaną przez pracowników danej organizacji. Zwłaszcza w dobie nowej gospodarki, w czasie rozwoju znaczenia organizacji i pracowników wiedzy (Nogalski, Kowalczyk, 2007). Decyzje personalne zorientowane są zawsze w kontekście konkretnego człowieka, czy grup, zespołów zadaniowych. Są to podmioty, które charakteryzują się określoną specyfiką, określonymi parametrami kompetencji, motywacji, zaangażowania czy zdrowia. Dlatego zasadniczym aspektem z punktu widzenia istoty pomiaru kapitału ludzkiego jest próba oszacowania użyteczności decyzji personalnych w kontekście oceny skuteczności inwestycyjnej w posiadany kapitał ludzki przedsiębiorstwa. Jednym z bardziej kompatybilnych modeli oceny jakościowej do powyższych założeń jest model 
oceny użyteczności narzędzi selekcyjnych wg metody portfelowej Taylora-Rusella (Cascio, 2001, s. 207; Kawka, Chełpa, 2005, s. 494).

W wersji kanonicznej (wycena wartości użyteczności narzędzia selekcyjnego) jest to narzędzie do oceny użyteczności potencjalnego wdrożenia danej techniki selekcyjnej bazując na danych dotyczących wyników i jakości pracy zatrudnionych pracowników. Prosty dwuwymiarowy układ modeli portfelowych pozwala na jednoznaczne i łatwe interpretacje uzyskanych wyników. Metodykę takiego podejścia do szacowania oczekiwanej użyteczności technik selekcyjnych można zatem przenieść i transponować $z$ wąskiego obszaru decyzji personalnych zorientowanych na obszary związane $z$ całym systemowym podejściem do funkcji personalnej (zborem decyzji personalnych). Można na tej podstawie uzyskać, w zależności od liczby przyjętych obszarów zakresów decyzji personalnych, wieloetapowy, wielowątkowy proces oceny i pomiaru użyteczności podejmowanych praktyk personalnych w kontekście uzyskiwanych wyników przez danych pracowników. Nośnikiem oceny wartości kapitału ludzkiego byłoby powiązanie efektów uzyskanych przez pracowników w kontekście określonych praktyk decyzji personalnych. Im wyższy poziom użyteczności decyzji personalnych przy wysokim poziomie efektów pracy, tym potencjalnie wyższy poziom jakości i wartości kapitału ludzkiego.

Użyteczność kapitału ludzkiego może być uznana za jeden z bardziej czytelnych wymiarów oceny wpływu i znaczenia zarządzania zasobami ludzkimi na sukces organizacji. Pomiar użyteczności kapitału ludzkiego (odpowiednich zakresów decyzji personalnych w zarządzaniu kapitałem ludzkim) może być uznany za jeden z pośrednich wymiarów jego długofalowego pomiaru wartości. Próbą operacjonalizacji powyższych założeń może być aplikacja metodyki modelu Taylora-Russela pomiaru użyteczności określonych obszarów decyzji personalnych w kontekście wyników uzyskiwanych przez zatrudnionych pracowników.

\section{Model portfolio Taylora-Russela}

Najbardziej znany model użyteczności, który spełnia powyższe założenia implementacji do pomiaru kapitału ludzkiego, został opracowany przez Taylora-Russela, którzy oszacowali trzy parametry jej pomiaru (Cascio, 2001, s. 208):

- Współczynnik ważności (r) - korelacja między wydajnością przewidywaną szacowaną zgodnie z metodą selekcyjną a wydajnością realną pracowników,

- Współczynnik selekcji (SR) - odsetek wybranych kandydatów z danej puli badanych, 
- Wskaźnik bazowy (BR) - odsetek trafnie wybranych kandydatów bez zastosowania danej metody.

Przydatność i użyteczność stosowanej procedury doboru zawodowego można zatem weryfikować analizując jej efekty poprzez porównywanie przewidywanej i rzeczywistej sprawności zawodowej poddanych badaniu kandydatów. Porównanie sformułowanej na podstawie badań predykcji z rzeczywistą sprawnością zawodową kandydatów wymaga:

1. Standaryzacji procedury selekcyjnej tzn. ujednolicenia sposobu badania i niezmienności używanych narzędzi oraz stałości mierzonych kwalifikacji i kryteriów ich oceny, czyli stałości przyjźtych profili wymagań zawodowych.

2. Standaryzacji procedury oceny pracy tzn. ujednolicenia sposobu oraz używanych narzędzi oraz kryteriów oceny poziomu wykonywanej pracy.

3. Nie podejmowania w oparciu o wyniki badania przydatności zawodowej rzeczywistych decyzji kadrowych - selekcję przeprowadzają wówczas niezależni asesorzy, opierając siź o inne, odrębnie stosowane metody doboru.

Łatwość porównania predykcji i rzeczywistych osiągnięć zatrudnionych zapewnia przyjźcie dychotomiczności oceny formułowanej zarówno przy podejmowaniu decyzji kadrowej. Daje to możliwość stworzenia odpowiednich kategorii pracowniczych, wynikających z oceny potencjału pracowniczego w trakcie procedury selekcji, jak i na stanowisku pracy. Są to działania kadrowe: „odrzucenie” - „zatrudnienie”, jak i określanie poziomu wykonywania pracy „niezadowalający” „zadowalajacy”. Weryfikację użyteczności przyjtej procedury doboru zawodowego umożliwiają systematycznie gromadzone informacje. Dotyczą one predykcji formułowanych na podstawie badań przydatności zawodowej poszczególnych kandydatów, jak i oceny ich późniejszych, rzeczywistych wyników pracy. Czynnikiem sukcesu jest więc ogólnie pojęta i arbitralnie wybrana przez firmę wydajność, produktywność, czy efektywność uzyskanych przez pracownika wyników najczęściej korygowana o poziom jakości jego pracy. Inaczej mówiąc, wskaźnik sukcesu decyzji personalnej odgrywa rolę pomiaru wartości czy użyteczności określonego poziomu i nakładu inwestycji w dany kapitał ludzki. Istotź omawianego modelu w wersji kanonicznej, uwzględniającym dwuwymiarowość walidacji danej procedury selekcyjnej, prezentuje Rys. 1.

Istotę podziału danego potrfolia stanowią ustalone arbitralnie przez potrzeby organizacji górne granice (pułapy): poziomu kryterium oceny pracowniczej. To kryterium wyboru dzieli pracowników na grupy zadawalające i niezadawalające z punktu widzenia arbitralnie ustalonego poziomu osiąganych wyników pracy.

Drugi wymiar dotyczy określonego poziomu pułapu wartości na predykatorze decyzyjnym, który może wynikać albo z decyzji menedżerskich bądź z oceny zewnętrznego audytu personalnego potencjału pracowników (jest to 
ocena pośrednia, estymacja potencjału kapitału ludzkiego). Do zasadniczych źródeł, które mogą być podstawą do ustalenia pozytywnej bądź negatywnej decyzji kadrowej w następujących zakresach można zaliczyć przykładowo (predyktory decyzyjne realizujące cele strategii personalnej):

- zatrudnienie/zwolnienie,

- awans/brak promocji,

- podwyżka/brak podwyżki,

- przeszeregowanie płacowe/brak ruchu płacowego,

- inwestycja w rozwój i szkolenie/ brak szkoleń,

- udział w projekcie/ brak udziału w projekcie,

- przypisanie roli coacha, mentora/ brak tej roli,

- przydział bardziej odpowiedzialnego zadania/ brak przydziału,

- udział w planie następstw (kadra rezerwowa)/ brak udziału,

- zaliczenie do planu zarządzania talentami/ brak udziału

- inne decyzje personalne istotne z p. widzenia strategii personalnej firmy.

Rys. 1. Porfolio procedury modelu użyteczności Taylora-Russella

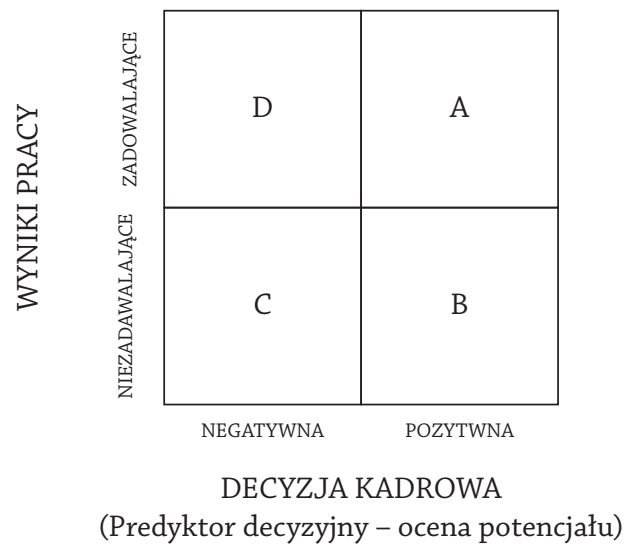

Źródło: Opracowanie własne na podstawie Cascio (1980, 2001)

Zasadniczą interpretacją analizy portfelowej wynikającej ze złożenia dwóch wymiarów, takich, jak:

1) wyniki pracy (kapitał zainwestowany),

2) predyktor decyzyjny - (oparty na potencjale kapitatu) jest wygenerowanie pośrednio 4 kategorii wartości kapitału ludzkiego: A, B, C, D.

Jak wskazuje metodyka porfolio procedury doboru zawodowego w wersji kanonicznej, zbierane dane dotyczą pracowników, które można podzielić na wskazane kategorie, symbolizują znaczenie posiadanego kapitału ludzkiego: 
A - liczba osób, które uzyskały pozytywną decyzję personalną i pozytywną ocenź wyników pracy, ewentualnie poziom roczny wynagrodzeń tak wyselekcjonowanej grupy pracowniczej - Kapitał ludzki zainwestowany z wysokim stopniem zwrotu.

B - liczba osób, które uzyskały pozytywną decyzję personalną oraz negatywną ocenę wyników pracy, ewentualnie poziom roczny wynagrodzeń tak wyselekcjonowanej grupy pracowniczej - Kapitał ludzki zainwestowany z niskim stopniem zwrotu.

C - liczba osób, które uzyskały negatywną decyzję personalną i negatywną ocenź wyników pracy, ewentualnie poziom roczny wynagrodzeń tak wyselekcjonowanej grupy pracowniczej - Kapitał ludzki niezainwestowany.

D - liczba osób, które uzyskały negatywną decyzję personalną oraz pozytywną ocenź wyników pracy, ewentualnie poziom roczny wynagrodzeń tak wyselekcjonowanej grupy pracowniczej - Kapitał ludzki niezainwestowany z utraconym potencjalnie wysokim stopniem zwrotu.

Pola A i C odpowiadają zatem trafnym decyzjom - jeśli przy wyborze kandydatów zastosowano by dane kryterium wyboru określonej decyzji personalnej. Pola B i D wskazują błędne decyzje, w interpretacji zarówno niechybionych inwestycji oraz potencjalnych utraconych korzyści wynikających z niezainwestowania w dany kapitał ludzki.

Do ustalenia użyteczności zastosowanej procedury doboru zawodowego (czy szerzej procesu personalnego) używając założeń danego modelu należy użyć następujących wzorów (Cascio, 1980, s. 25-45):

1) Wskaźnik sukcesu (powodzenia) decyzji personalnych bez zastosowania odpowiedniej procedury personalnej(wskaźnik bazowy):

$$
\mathrm{W}_{\mathrm{B}}=\frac{\mathrm{A}+\mathrm{D}}{\mathrm{A}+\mathrm{B}+\mathrm{C}+\mathrm{D}[\mathrm{N}]}
$$

2) Wskaźnik sukcesu (powodzenia) decyzji personalnej przy zastosowaniu odpowiedniej procedury personalnej

$$
\mathrm{W}_{\mathrm{P}}=\frac{\mathrm{A}}{\mathrm{A}+\mathrm{B}}
$$

3) Wskaźnik powodzenia zarządzania kapitałem ludzkim, pośredni wskaźnik użyteczności kapitału ludzkiego w zakresie danej decyzji personalnej

$\mathrm{WU}_{\mathrm{KL}}=\frac{\mathrm{A}}{\mathrm{A}+\mathrm{B}}-\frac{\mathrm{A}+\mathrm{D}}{\mathrm{N}}$ 
gdzie można interpretować powyższy wskaźnik także, jako procentowy oczekiwany wzrost liczby pracowników w kategorii A po zastosowaniu danej nowej procedury doboru (danej procedury personalnej). Odniesienie się zamiennie do wartości rocznej wynagrodzeń danego wolumenu pracowników ulokowanych w danych częściach macierzy, możemy również uzyskać wskaźnik oceny użyteczności płacowej inwestycji w kapitał ludzki. Inaczej mówiąc możemy dokonać pomiaru realizacji funkcji inwestycyjnej wynagrodzeń w danym modelu zarządzania kapitałem ludzkim.

Inną możliwą miarą oceny użyteczności przyjętej procedury personalnej jest porównanie potencjalnych niepowodzeń kadrowych, które zostałyby wyeliminowane wskutek danej decyzji personalnej potencjalnymi powodzeniami kadrowymi, które dana decyzja by uniemożliwiła (negatywna prognoza zawodowa). A zatem, porównywane są zarówno trafne decyzje personalne (zysk z decyzji), jak i nieefektywne (koszt decyzji). Dane potrzebne do oszacowania użyteczności procedury doboru oblicza siź w nastźpujący sposób (Guliford, 1964):

4) Zysk danej decyzji personalnej $Z_{D P}=\frac{C}{B+C}$

5) Koszt danej decyzji personalnej $\mathrm{K}_{\mathrm{DP}}=\frac{\mathrm{A}}{\mathrm{A}+\mathrm{D}}$.

Tab. 1. Interpretacja wskaźników użyteczności procedur doboru zawodowego $\mathrm{WU}_{\mathrm{KL}}$

\begin{tabular}{|c|c|c|}
\hline \multirow{2}{*}{ Uzyskane wskaźniki } & \multicolumn{2}{|c|}{$\begin{array}{c}\text { Interpretacja użyteczności procedury doboru (decyzji personal- } \\
\text { nej) }\end{array}$} \\
& LIBERALNA & RESTRYKCYJNA \\
\hline poniżej 0,20 & MAŁA & BARDZO MAŁA \\
\hline $0,20-0,29$ & WYSTARCZAJ CA & \multirow{2}{*}{ MAŁA } \\
\hline $0,30-0,39$ & DUŻA & \multirow{2}{*}{ WYSTARCZAJ CA } \\
\hline $0,40-0,49$ & BARDZO DUŻA & DUŻA \\
\hline $0,50-0,70$ & & BARDZO DUŻA \\
\hline $0,71-0,90$ & & \\
\hline $0,91-1,00$ & & \\
\hline
\end{tabular}

Żródło: Armstrong, 2006; Guliford, 1964. 
Otrzymywane dzięki obliczeniom wskaźniki użyteczności danych decyzji personalnych, szczególnie w kontekście oceny wartości efektów pracy, mogą nastręczać trudności interpretacyjne w zależności od poziomu selektywności i restrykcyjności wartości predyktora, jak i kryterium wyboru. Po za tym czynnikiem mogącym zaciemniać i wypaczać wiarygodność uzyskanych wyników - w wersji dedykowanej tylko dla decyzji selekcyjnych jest fakt, że powyższe pomiary odnoszą się do populacji pracowników, którzy już są w organizacji i mogli być dobierani na podstawie innych metod i technik niż oceniana nowa procedura selekcji (proces personalny). Dlatego też można wskazać dwa potencjalne podejścia do tego zagadnienia (zob. Tab. 1).

\section{Podsumowanie}

Aby wyliczyć całkowitą końcową, syntetyczną wartość użyteczności kapitału ludzkiego $\left[\mathrm{SWU}_{\mathrm{KL}}\right] \mathrm{w}$ danej organizacji, należy dokonać pomiaru średniej sumarycznej wartości wskaźnika, liczonego iteracyjnie n razy - w kontekście użytych n predykatorów decyzyjnych, czyli n - obszarów decyzji personalnych uważanych za najważniejsze dla strategii organizacji. Będzie to zatem średnia (może być ważona, w zależności od arbitrażu zarządu, które decyzje można wskazać jako kluczowe) wskaźników użyteczności kapitału ludzkiego w kontekście wszystkich decyzji personalnych podjętych $\mathrm{w}$ danym czasie $\mathrm{w}$ odniesieniu do grupy pracowników w badanej organizacji. To zapewni bardziej dokładne estymowanie potencjalnej wartości kapitału ludzkiego w kontekście systemowego podejścia do strategii personalnej.

Wskaźnik przeciętnego (ważonej) powodzenia zarządzania kapitałem ludzkim, pośredni wskaźnik użyteczności kapitału ludzkiego w kontekście systemowego podejścia do funkcji personalnej

6) $\mathrm{SWU}_{\mathrm{KL}}=\left[\sum_{\mathrm{i}=1}^{\mathrm{n}} \mathrm{WU}_{\mathrm{KL}}\right] * \frac{1}{\mathrm{n}}$.

Przy opisywaniu możliwości implementacji powyższego modelu nie można nie wskazać na ograniczenia wynikające ze stosowania rozwiązań tego modelu do estymacji wartości kapitału ludzkiego. Podstawowym czynnikiem mogącym zakłócać implementację powyższych założeń i wzorów jest brak ścisłego powiązania treści danego modelu z użytecznością bezpośrednią, wyrażaną przede wszystkim w wartościach pieniężnych. Dlatego autor wskazuje na próbę zamiany liczby pracowników na poziom ich dochodów czerpanych w tym okresie z tytułu 
zatrudnienia u danego pracodawcy. Jest to o tyle istotne, gdyż sprowadzenie do wspólnego, obiektywnego mianownika, którym niewątpliwie jest ekonomiczny zwrot - w oryginalnej wersji modelu TR - ze stosowanych technik i procedur selekcji, czy w szerszym rozumieniu decyzji personalnych, pozwala na większą porównywalność odpowiednich procedur w zakresie zarządzania zasobami ludzkimi. Możemy wtedy mówić o bezpośredniej użyteczności (np. w jednej organizacji liczba osób jest sprawą istotną w stosunku do spodziewanych korzyści, z kolei w innej firmie specjalistyczny poziom wiedzy awansowanego pracownika stanowi istotną przesłankę strategicznej przewagi). A to z kolei może przekładać się na bardziej porównywalne oszacowania wartości kapitału ludzkiego między różnymi podmiotami organizacyjnymi.

Analizując metodykę modelu TR należy podkreślić, iż dane granice budujące potencjalne obszary A, B, C i D zostają tutaj w zasadzie wyznaczone arbitralnie przez kierownictwo firmy (bądź jeszcze lepiej przez specjalistów, ekspertów z zewnątrz firmy, audytorów). Ich przekroczenie nie jest więc w żaden jakościowy sposób odnotowywane przez ewentualny wzrost poziomu użyteczności decyzji personalnych (Chełpa, Kawka, 2005, s. 498). Różnice w kompetencjach i potencjale pracowników powinny w dłuższej perspektywie wpływać na określony poziom użyteczności decyzji personalnych. Powyżej tak określonych granic model zachowuje wartości stałe użyteczności, co jest oczywiście błędem dokładności pomiaru.

W tym świetle należy więc na koniec wskazać na najistotniejszą zaletę próby implementacji założeń modelu TR w kontekście oceny wartości kapitału ludzkiego przedsiębiorstwa. Wartość kapitału ludzkiego może być szacowana jako pośredni wskaźnik dotyczący analizy następujących zależności uchwyconych w następstwie analiz modelu TR. W tym świetle do zasadniczych konkluzji implementacji modelu TR w zakresie wyceny wartości kapitału ludzkiego można zaliczyć następującą zależność:

- im wyższy stopień kryterium wyboru efektywności zainwestowania w kapitał ludzki (większy stopień wskaźnika BR), oraz

- im niższy stopień współczynnika selektywności w danym obszarze decyzyjnym (niższy stopień wskaźnika SR),

- a wolumen zatrudnienia i wartości wynagrodzeń pracowników z obszaru A jest niezmienny bądź niemalejący -

- świadczyć to może o potencjalnie wysokim stopniu wartości kapitału ludzkiego.

Tak sformułowany tok analizy wartości kapitału ludzkiego na podstawie próby implementacji modelu portfolio Taylora-Russela stanowić może łatwy w aplikacji i zrozumiały dla interesariuszy, krok do operacjonalizacji bardzo trudnego 
i złożonego problemu pomiaru i sprawozdawczości kapitału ludzkiego w organizacji.

\section{Bibliografia}

Armstrong, M. (1996), Zarzqdzanie zasobami ludzkimi. Strategia i działanie, Wydawnictwo Profesjonalnej Szkoły Biznesu, Kraków.

Bochniarz, P., Gugała, K. (2005), Budowanie i pomiar kapitału ludzkiego w firmie, Poletxt Warszawa.

Bolesta-Kukułka, K. (2003), Decyzje menedżerskie, PWE, Warszawa.

Bratnicki, M., Strużyna, J. (2001) (red.), Przedsiębiorczość i kapitał intelektualny, Wydawnictwo AE Katowice, Katowice.

Cascio, W.F. (2001), Kalkulacja kosztów zasobów ludzkich, Oficyna Ekonomiczna, Kraków.

Cascio, W.F. (1980), Responding to the demand for accountability: A critical analysis of three utility models, "Organizational Behavior and Human Performance", nr 25.

Chełpa, S., Kawka, T. (2005), Weryfikowanie procedur użyteczności doboru zawodowego, w: T. Witkowski (red.), Dobór personelu, Biblioteka Moderatora, Staszów.

Cronbach, L.J., Gleser, G.C. (1965) (red.), Psychological Tests and Personel Decisions Glesler Univeristy of Illinois Press, Urbana.

Domański, S.R. (1993), Kapitał ludzki i wzrost gospodarczy, PWN, Warszawa.

Edvinsson, L., Malone, A.S. (2001), Kapitat intelektualny, PWN, Warszawa.

Guilford, J.P. (1964), Podstawowe metody statystyczne w psychologii i pedagogice, PWN, Warszawa.

Lipka, A. (2012), Zaufanie w metodach wyceny kapitału ludzkiego organizacji, w: „Zarządzanie i Finanse”, red. W. Golanu, nr 2012, Wydawnictwo UG Gdańsk.

Listwan, T. (2010) (red.), Zarzadzanie kadrami, CH Beck, Warszawa.

Łukasiewicz, G. (2009), Kapitał ludzki organizacji. Pomiar i sprawozdawczość, Wydawnictwo Naukowe PWN, Warszawa.

Nogalski, B., Kowalczyk, A. (2007), Zarzadzanie wiedza. Koncepcje i narzędzia, Difin, Warszawa.

Rybak, M. (2003) (red.), Kapitał ludzki a konkurencyjność przedsiębiorstw, Poltext, Warszawa.

Stabryła, A. (2000), Zarzadzanie strategiczne $w$ teorii i praktyce firmy, Wydawnictwo Naukowe PWN, Warszawa.

Strużyna, J. (2000), Wymiary kapitału ludzkiego firmy, w: B. Kożusznik (red.), Kształtowanie kapitału ludzkiego firmy, Uniwersytet w Białymstoku, Białystok.

Wawrzyniak, B. (2001), Projektowanie strategii personalnej $w$ przedsiębiorstwie, w: A. Ludwiczyński, K. Strobińska (red.), Zarzadzanie strategiczne kapitałem ludzkim, Poltext, Warszawa. 
Mikuła, B., Piertuszak-Ortyl, A., Potocki A. (2002) (red.), Zarzq̨dzanie przedsiębiorstwem XXI wieku. Wybrane koncepcje i metody, Diffin, Warszawa.

\section{Summary}

\section{Taylor-Russell Model as Example of Portfolio Approach to Human Capital Measurement}

This article is an attempt to conceptualize a utility model of selection methods by Taylor-Russell (TR) to adapt it to the measurement of human capital. On the basis of methodological assumptions of the TR model there is an analysis for implementation portfolio techniques in the reporting of human capital. The main point is conceptual transposition and substitution criteria in the original predictive model for personal decision criteria. As a result, it is assumed that the value of human capital is thus a function of a utility of implementation appropriate processes and human resource management programs. Personal decision that turns out to be successful (optimal) due to taken aims and resources is determined by two dimensions: the process of decision-making and the value of human capital, in relation to which decisions are made.

Keywords: human capital, portfolio models, personnel decisions, utility, Taylor Russell model.

\section{Резюме}

\section{Модель Тэймора - Рассела как пример портфельного подхода к измерению чемовеческого капитала}

Статья представляет собой попытку концептуализации модели полезности методов профессионального отбора Тэйлора - Рассела с точки зрения ее адаптации к условиям измерения человеческого капитала. На основании методических положений модели TR проводится анализ применения портфельных техник в отчетности, касающейся человеческого капитала. Главной концептуальной основой является транспозиция и замена прогностических критериев в подлинной модели критериями, упорядочивающими принятие кадровых решений. В результате принята концепция, 
что стоимость человеческого капитала является функцией полезности реализации соответствующих процессов и программ управления человеческими ресурсами. Кадровое решение, которое оказывается правильным (оптимальным) благодаря поставленным целям и принятым доступным организации мерам, обусловлено двумя элементами: процессом принятия решений и стоимостью человеческого капитала, по отношению к которому принимаются решения.

Ключевые слова: человеческий капитал, портфельные модели, кадровые решения, полезность, модель Тэйлора - Рассела.

\section{dr Tomasz Kawka}

Adiunkt w Katedrze Zarządzania Kadrami, Uniwersytet Ekonomiczny we Wrocławiu. Zainteresowania naukowe dotyczą badań nad systemami wynagrodzeń oraz motywowania pracowników w kontekście nowej gospodarki, a także uwarunkowań zarządzania kapitałem ludzkim w organizacjach sportowych. Autor ponad 50 publikacji na temat funkcji personalnej, wieloletni organizator Konferencji Sukces w Zarządzaniu Kadrami oraz Kierownik Studium Podyplomowego Nowoczesne Zarządzania Kadrami, niezależny trener ekspert i doradca w zakresie wartościowania pracy, budowania systemów płacowych współpracujący z ponad 15 firmami konsultingowo-doradczymi. 
